\title{
Article \\ Electrochemical Detection of Electrolytes Using a Solid-State Ion-Selective Electrode of Single-Piece Type Membrane
}

\author{
Li-Da Chen ${ }^{1}$, Wei-Jhen Wang ${ }^{1}$ and Gou-Jen Wang ${ }^{1,2,3, *}$ \\ 1 Department of Mechanical Engineering, National Chung-Hsing University, Taichung 40227, Taiwan; \\ 40332131@gm.nfu.edu.tw (L.-D.C.); freedom84528@gmail.com (W.-J.W.) \\ 2 Graduate Institute of Biomedical Engineering, National Chung-Hsing University, Taichung 40227, Taiwan \\ 3 Regenerative Medicine and Cell Therapy Research Center, Kaohsiung Medical University, \\ Kaohsiung 80708, Taiwan \\ * Correspondence: gjwang@dragon.nchu.edu.tw
}

check for

updates

Citation: Chen, L.-D.; Wang, W.-J.; Wang, G.-J. Electrochemical Detection of Electrolytes Using a Solid-State Ion-Selective Electrode of

Single-Piece Type Membrane. Biosensors 2021, 11, 109. https:// doi.org/10.3390/bios11040109

Received: 1 March 2021

Accepted: 4 April 2021

Published: 7 April 2021

Publisher's Note: MDPI stays neutral with regard to jurisdictional claims in published maps and institutional affiliations.

Copyright: (c) 2021 by the authors. Licensee MDPI, Basel, Switzerland. This article is an open access article distributed under the terms and conditions of the Creative Commons Attribution (CC BY) license (https:/ / creativecommons.org/licenses/by/ $4.0 /)$.

\begin{abstract}
This study aimed to develop simple electrochemical electrodes for the fast detection of chloride, sodium and potassium ions in human serum. A flat thin-film gold electrode was used as the detection electrode for chloride ions; a single-piece type membrane based solid-state ion-selective electrode (ISE), which was formed by covering a flat thin-film gold electrode with a mixture of 7,7,8,8tetracyanoquinodimethane (TCNQ) and ion-selective membrane (ISM), was developed for sodium and potassium ions detection. Through cyclic voltammetry (CV) and square-wave voltammetry (SWV), the detection data can be obtained within two minutes. The linear detection ranges in the standard samples of chloride, sodium, and potassium ions were $25-200 \mathrm{mM}, 50-200 \mathrm{mM}$, and 2-10 $\mathrm{mM}$, with the average relative standard deviation (RSD) of $0.79 \%, 1.65 \%$, and $0.47 \%$ and the average recovery rates of $101 \%, 100 \%$ and $96 \%$, respectively. Interference experiments with $\mathrm{Na}^{+}, \mathrm{K}^{+}$, $\mathrm{Cl}^{-}, \mathrm{Ca}^{2+}$, and $\mathrm{Mg}^{2+}$ ions demonstrated that the proposed detection electrodes have good selectivity. Moreover, the proposed detection electrodes have characteristics such as the ability to be prepared under relatively simple process conditions, excellent detection sensitivity, and low RSD, and the detection linear range is suitable for the $\mathrm{Cl}^{-}, \mathrm{Na}^{+}$and $\mathrm{K}^{+}$concentrations in human serum.
\end{abstract}

Keywords: solid-state ion-selective electrode; electrochemical detection of electrolytes; cyclic voltammetry; square-wave voltammetry

\section{Introduction}

The chloride, sodium and potassium ions in the human body can maintain the physiological functions of water metabolism, the neuromuscular system, acid-base balance and osmotic pressure in the body. Therefore, the metabolic functions of the human body can be evaluated based on the measurements of the chloride, sodium and potassium ions concentrations in the body [1-4].

The concentrations of chloride, sodium, and potassium ions in normal human serum are 98-106 mM [2], 135-145 mM [3] and 3.5-5 mM [3], respectively. Too-high concentrations in the human body will cause hyperchloremia, hypernatremia, and hyperkalemia, while the occurrence of concentrations lower than the normal concentration will cause hypochloremia, hyponatremia, and hypoxemia potassium. Another common chloriderelated disease is cystic fibrosis, which is an autosomal recessive genetic disease that affects mucus-producing cells in the body and causes mucus accumulation in the lungs, trachea, and digestive tract, leading to the degradation of breathing functions [5]. The general clinical diagnosis of this disease is based on measuring the chloride ion content in sweat. People with the disease usually have a chloride ion content of over $60 \mathrm{mM}$ in their sweat [2], while the chloride ion content in normal human sweat is below $40 \mathrm{mM}$ [5].

The laboratory autoanalyzer is a general electrolyte-detecting instrument that can provide doctors with reliable results. However, the specimen must be delivered to a 
specific laboratory and diluted before indirect ion-selective electrodes (ISEs) are used for detection. For patients with a severe or life-threatening degree of the illness, the blood gas analyzer (BGA) is usually used clinically to achieve rapid detection. The BGA uses direct ISE for direct analysis without the need to first dilute the sample, and the results can be obtained within 1 to $5 \mathrm{~min}$ [6-10]. The BGA can be divided into two types: benchtop and portable. The benchtop BGA detection cartridge has a service life of about 28-30 days; hence, it is suitable for mass detection applications. However, the instrument needs regular calibration and maintenance. The portable BGA usually uses a disposable detection cassette, which can reduce the frequency of instrument calibration and maintenance; however, since the cassette cannot be reused, the portable BGA is only suitable for smallvolume detection applications [11]. In recent years, as the utilization rate of point-of-care (POC) testing has significantly increased, the economic value of POC-related products has also increased [12]. Therefore, there are many portable and small BGAs and electrolyte analyzer-related products in the market, such as Abbott i-STAT [13], Siemens epoc ${ }^{\circledR}$ blood analysis system [12], and Arkray Spotchem EL SE-1520 [14].

At present, the electrochemical potentiometric method [13-18] is the main method for electrolyte ions quantification. Other detection methods include the conductivity method [19,20], cyclic voltammetry (CV) [21-26], and coulometry [27,28]. The potentiometric method uses liquid-state ISEs that need to be regularly replaced. The operating temperature is limited, and the electrodes cannot be effectively miniaturized [29-31]. Moreover, the practical application of the conductance method is not yet mature [21]. Therefore, in the current study, a novel detection method combining high-sensitivity voltammetry and solid-state ISE is developed. The solid-state ISE does not need to be filled with a solution. The ion-selective membrane directly contacts the electrode, and the solid contact material of the intermediate layer is added to enhance the effect of ion and electron conversion. Therefore, the sensor can be more easily miniaturized, and its durability and operating temperature range are improved.

Commonly used solid contact materials include high-molecular-weight conductive polymers such as polypyrroles [32], poly(3-octylthiophene) [33], and poly(3,4-ethylenedioxythiophene) (PEDOT) [34]. Nanomaterials used as solid contact materials include carbon nanotubes [17], graphene [35], platinum nanoparticles [36], and noble metal nanostructures [37]. Electroactive substances are also used, such as tetrathiafulvalene [38] and 7,7,8,8-tetracyanoquinodimethane (TCNQ) [39]. Conductive polymers such as PEDOT need to be synthesized via electrochemical polymerization [34], while nanomaterials need to be produced via electrochemical deposition [37]. The manufacturing processes of both are relatively cumbersome. Therefore, this study uses the solid-state contact conduction mechanism of high redox capacitors [29] and adopts the electroactive material TCNQ as the solid-state contact material.

TCNQ is a powerful organic electron acceptor with excellent electrical properties and high electron affinity (2.88 eV) [40]; thus, it can easily donate electron acceptors to react with transition metals or organic compounds and form numerous TCNQ anion-based salt complexes, such as CuTCNQ [40], AgTCNQ [40], KTCNQ [39], and NaTCNQ [39]. In addition, the use of the TCNQ involves a simple process; the TCNQ only needs to be dropped on the electrode substrate through drop-casting [39].

In this study, electrodes for the effective and fast detection of electrolytes in human serum were developed. A flat thin-film gold electrode was used as the detection electrode for chloride ions and a solid-state ISE, which was formed by covering a flat thin-film gold electrode with a mixture of TCNQ and ion-selective membrane (ISM), was developed for sodium and potassium ions detection, respectively.

\section{Materials and Methods}

\subsection{Materials and Reagents}

TCNQ, tetrahydrofuran (THF), potassium chloride, sodium chloride, calcium chloride, magnesium chloride, human serum, potassium ionophore I, poly(vinyl chloride) and 
potassium phosphate monobasic were purchased from Sigma-Aldrich (St. Louis, MO, USA). Potassium ferricyanide and potassium ferrocyanide were purchased from SHOWA (Tokyo, Japan). Potassium tetrakis (4-chlorophenyl)borate, 2-nitrophenyl octyl ether, and 4-tertbutylcalix[4]arenetetraacetic acid tetraethyl ester were purchased from Thermo (Darmstadt, Germany). Sodium phosphate dibasic was purchased from J. T. Baker (USA). Acetone was purchased from ECHO Chemical (Miaoli, Taiwan). Distilled deionized water (>18 M $\Omega$ ) was obtained from ELGA LabWater (London, UK).

\subsection{Electrode Fabrication}

Scheme 1 illustrates the fabrication process of the chloride, potassium, and sodium ions detection electrodes. First, a thin gold layer was sputtered onto a $3 \times 5 \mathrm{~mm}^{2}$ polyethylene terephthalate (PET) membrane (Scheme 1A). Then, the gold thin-film-sputtered PET membrane was packaged to form the detection chip (Scheme 1B). For the potassium and sodium ions detection electrodes, $3 \mu \mathrm{L}$ of a TCNQ and ISM mixture solution was dripped onto the electrode (Scheme 1C). Table 1 presents the compositions and contents of potassium and sodium ISMs.

(A)

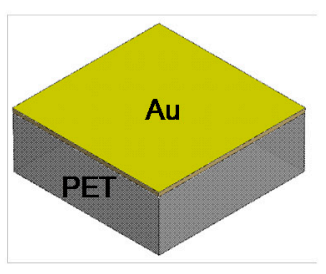

(B)

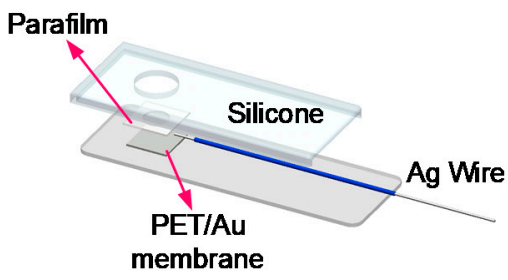

(C)

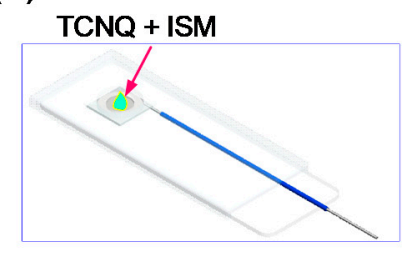

Scheme 1. Fabrication process of the chloride, potassium, and sodium ions detection electrodes: (A) sputtering of Au thinfilm on a polyethylene terephthalate (PET) membrane; (B) packaging; (C) dropping of 7,7,8,8-tetracyanoquinodimethane (TCNQ) + ion-selective membrane (ISM) mixture solution (potassium and sodium ions detection electrodes).

Table 1. Compositions and contents of potassium and sodium-ion-selective membrane.

\begin{tabular}{ccc}
\hline \multirow{2}{*}{ Reagents } & \multicolumn{2}{c}{ Target Ion } \\
\cline { 2 - 3 } & $\mathbf{K}^{+}$ & $\mathbf{N a}^{+}$ \\
\hline Potassium ionophore I & $14 \mathrm{mg}$ & 0 \\
\hline $\begin{array}{c}\text { 4-tert- } \\
\text { Butylcalix[4]arenetetraacetic } \\
\text { acid tetraethyl ester }\end{array}$ & 0 & $9.9 \mathrm{mg}$ \\
\hline $\begin{array}{c}\text { Potassium tetrakis } \\
\text { (4-chlorophenyl)borate }\end{array}$ & $3 \mathrm{mg}$ & $2.5 \mathrm{mg}$ \\
\hline $\begin{array}{c}\text { Polyvinyl chloride } \\
\text { (high-molecular-weight) }\end{array}$ & $328 \mathrm{mg}$ & $329 \mathrm{mg}$ \\
\hline 2-Nitrophenyl octyl ether & $0.63 \mathrm{~mL}$ & $0.63 \mathrm{~mL}$ \\
\hline
\end{tabular}

\subsection{Apparatus}

Cyclic voltammetry and square-wave voltammetry (SWV) were conducted with an SP-150 potentiostat (BioLogic, Seyssinet-Pariset, France) connected to a computer. A three-electrode system, consisting of a working electrode, a platinum counter electrode, and an $\mathrm{Ag} / \mathrm{AgCl}$ reference electrode, was applied. Field-emission scanning electron microscopy (FE-SEM, Zeiss UltraPlus, Potsdam, Germany) was used for the electrode surface characterization. The analysis system and the electrodes are shown in Figure 1. 


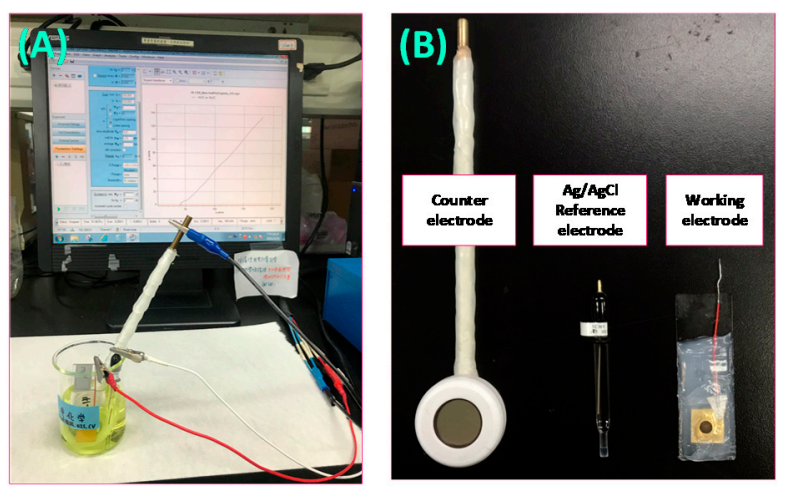

Figure 1. The analysis system: (A) experimental setup; (B) electrodes for the experiment.

\section{Results and Discussion}

\subsection{Optimization of Detection Electrodes}

Two parameters of the detection electrode need to be optimized-the organic solvent to dissolve TCNQ and the volume ratio of TCNQ to ISM. Regarding the organic solvent, a suitable solvent for TCNQ was selected from two organic solvents: acetone and THF. The TCNQ solution was mixed with the corresponding ISM $\left(\mathrm{Na}^{+}\right.$and $\left.\mathrm{K}^{+}\right)$with a volume ratio of 1:1 to determine which was the more suitable solvent. After the suitable TCNQ solvent was selected, TCNQ/ISM mixed solutions with different volume ratios $(1: 1,1: 2,2: 1,3: 1)$ were prepared to optimize the volume ratio.

Figure $2 \mathrm{~A}, \mathrm{~B}$ show the cyclic voltammograms for $\mathrm{Na}^{+}(140 \mathrm{mM} \mathrm{NaCl})$ and $\mathrm{K}^{+}(5 \mathrm{mM}$ $\mathrm{KCl}$ ) detections, respectively. The acetone-dissolved TCNQ resulted in peak oxidation currents at 0.46 and $0.50 \mathrm{~V}$ for $\mathrm{Na}^{+}$and $\mathrm{K}^{+}$detections, respectively. The peak oxidation currents were much higher than those obtained from the THF-dissolved TCNQ. Therefore, acetone was selected as the TCNQ solvent. The cyclic voltammograms for $\mathrm{Na}^{+}$and $\mathrm{K}^{+}$ detections with different TCNQ/ISM volume ratios are shown in Figure 2C,D, respectively. The results show that for the $\mathrm{Na}^{+}$detection, the TCNQ/ISM volume ratio of 2:1 resulted in the maximum peak oxidation current at $0.45 \mathrm{~V}$, while for the $\mathrm{K}^{+}$detection, the ratio of 3:1 resulted in the maximum peak oxidation current at $0.43 \mathrm{~V}$. In Figure $2 \mathrm{C}, \mathrm{D}$, as the TCNQ content increases, the oxidation potentials of $\mathrm{Na}^{+}$and $\mathrm{K}^{+}$shift to the left. Therefore, using a lower potential can drive the oxidation reaction and reduce the scanning voltage range during $C V$.

\subsection{Characterization of Fabricated Electrodes}

Figure 3 displays the scanning electron microscopy (SEM) images of the fabricated electrodes. The top view shows many typical TCNQ black blocks and a few white flake structures. The white flake structures are TCNQ erected under the influence of gravity [41]. The cross-sectional view (Figure 3B) shows that the thickness of the deposited $\mathrm{Na}^{+}$ISM and $\mathrm{K}^{+}$ISM layers: about 24.4 and $14.6 \mu \mathrm{m}$, respectively. 
(A)

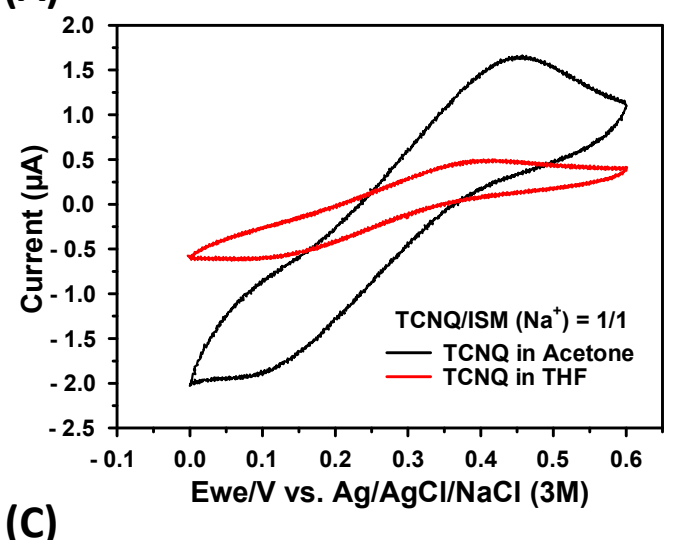

(C)

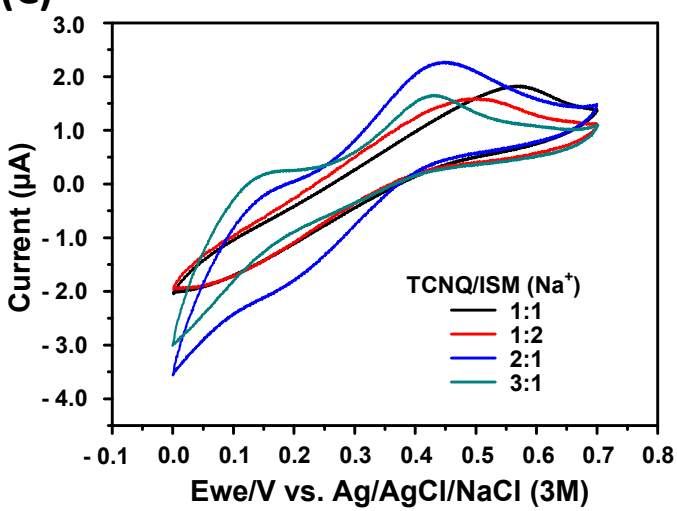

(B)

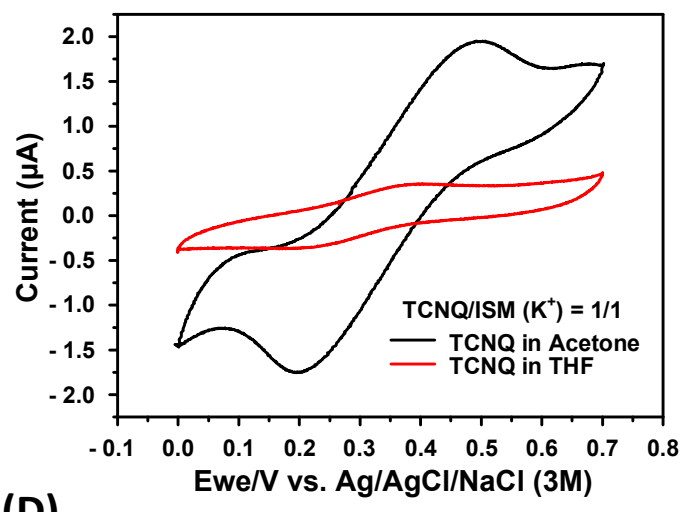

(D)

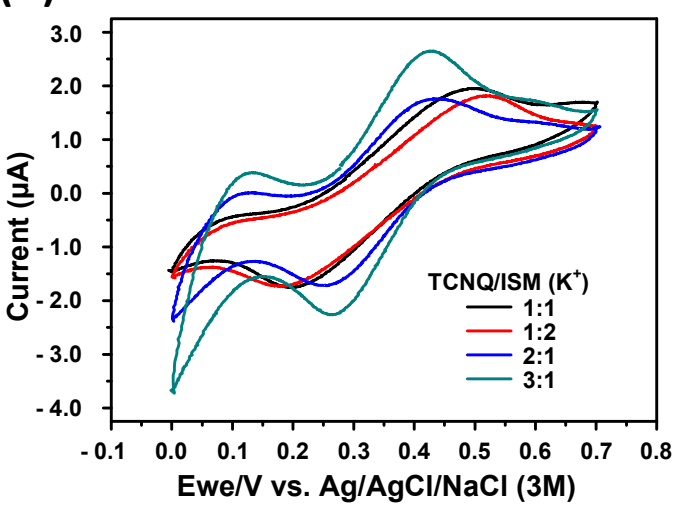

Figure 2. Cyclic voltammograms for TCNQ solvent selection and TCNQ/ISM volume ratio optimization: (A,B) cyclic voltammograms for $\mathrm{Na}^{+}(140 \mathrm{mM} \mathrm{NaCl})$ and $\mathrm{K}^{+}(5 \mathrm{mM} \mathrm{KCl})$ detections, respectively; (C,D) cyclic voltammograms for $\mathrm{Na}^{+}$ and $\mathrm{K}^{+}$detections with different TCNQ/ISM volume ratios, respectively.
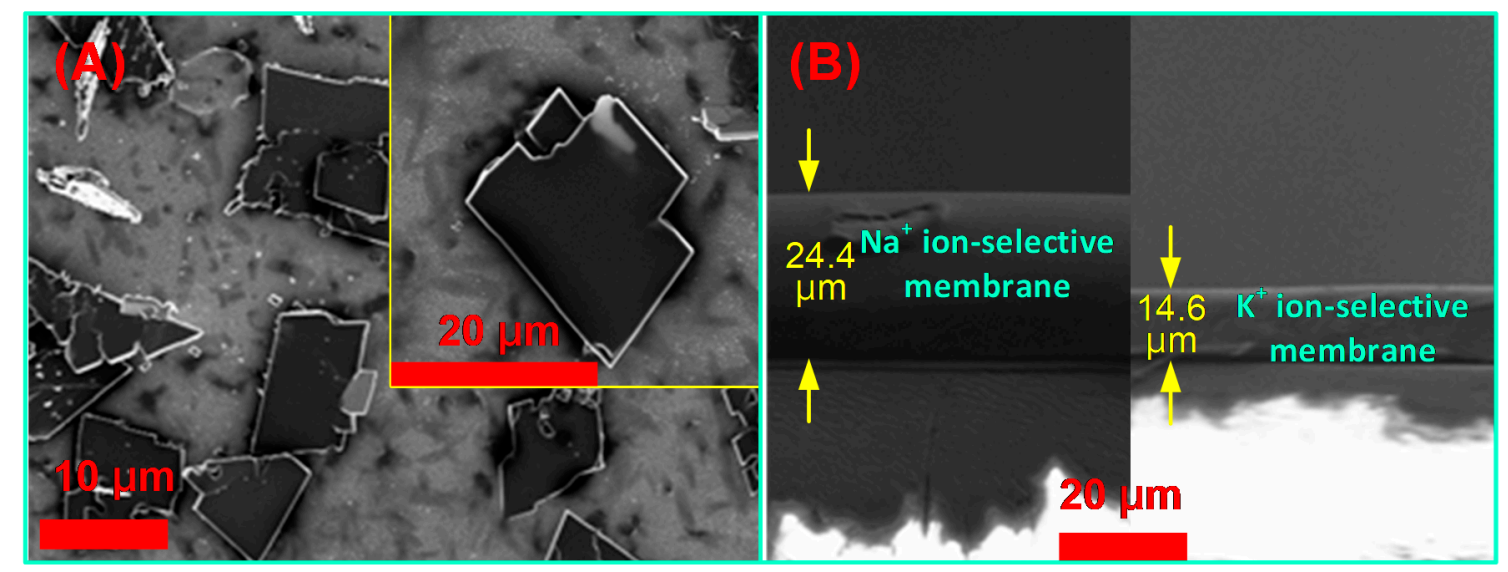

Figure 3. Scanning electron microscopy (SEM) images of electrode surface: (A) TCNQ/ion-selective membrane (ISM) deposited electrode (top view); (B) cross-sectional view.

\subsection{The Electrochemical Behavior of $\mathrm{Cl}^{-}, \mathrm{Na}^{+}$, and $\mathrm{K}^{+}$Electrodes}

The electron diffusion rate can be used to study the characteristics of electrochemical electrodes. The oxidation and reduction potentials, as well as the reaction current of the analyte, can be obtained based on a CV analysis of the reaction between the analyte and the electrode. The results can be used to determine whether the reaction is diffusion-controlled. 
Figure 4 shows the $\mathrm{CV}$ results of the proposed different electrodes at scan rates ranging from 100 to $500 \mathrm{mV} / \mathrm{s}$ in $50 \mathrm{mM} \mathrm{KCl}, 140 \mathrm{mM} \mathrm{NaCl}$, and $1 \mathrm{mM} \mathrm{KCl}$ solutions. The cyclic voltammograms displayed in Figure 4(A1-C1) show that the absolute value of the oxidation and reduction peak currents increased with the increase in scan rate. Generally, the Randles-Sevcik equation (Equation (1) is used to evaluate the diffusion-controlled characteristic of a sensing electrode.

$$
i_{p}=2.69 \times 10^{5} \times n^{3 / 2} \times A \times C \times D^{1 / 2} \times v^{1 / 2}
$$

where $i_{p}$ is the peak current, $n$ is the number of electrons appearing in a half-reaction for the redox couple, $A$ is the electrode area $\left(\mathrm{cm}^{2}\right), C$ is the analyte concentration $\left(\mathrm{mole} / \mathrm{cm}^{3}\right), D$ is the analyte diffusivity $\left(\mathrm{cm}^{2} / \mathrm{s}\right)$, and $v$ is the scan rate of potential $(\mathrm{V} / \mathrm{s})$. For stationary $n, A$, $C$, and $D, i_{p}$ is a linear function of the square root of the scanning rate. The corresponding linear relationship between the peak current and the square root of the scanning rate of the proposed electrodes for the cyclic voltammograms shown in Figure 4A1-C1 are given in Figure 4A2-C2, respectively. The $R^{2}$ values were calculated to be $0.9986,0.9981$, and 0.9989 , respectively. The results demonstrate that the proposed electrodes possess a typical diffusion-controlled electrochemical characteristic; hence, the electrodes are suitable for practical quantitative analyses.

(A1)

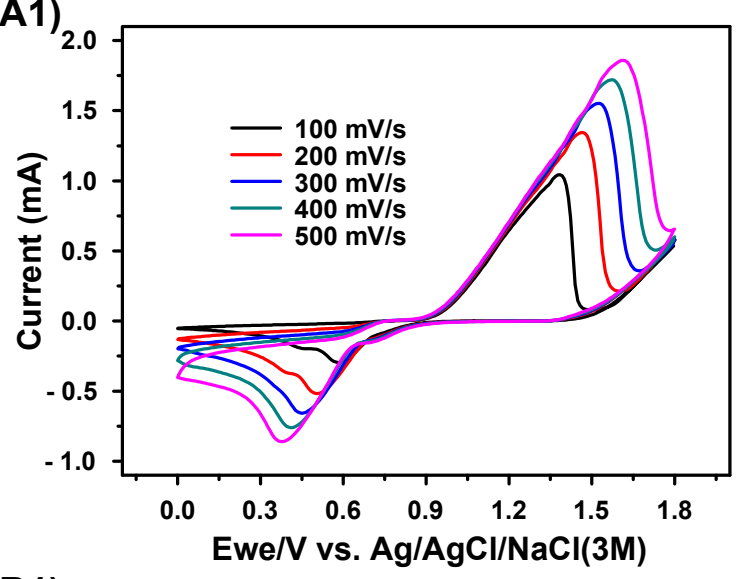

(B1)

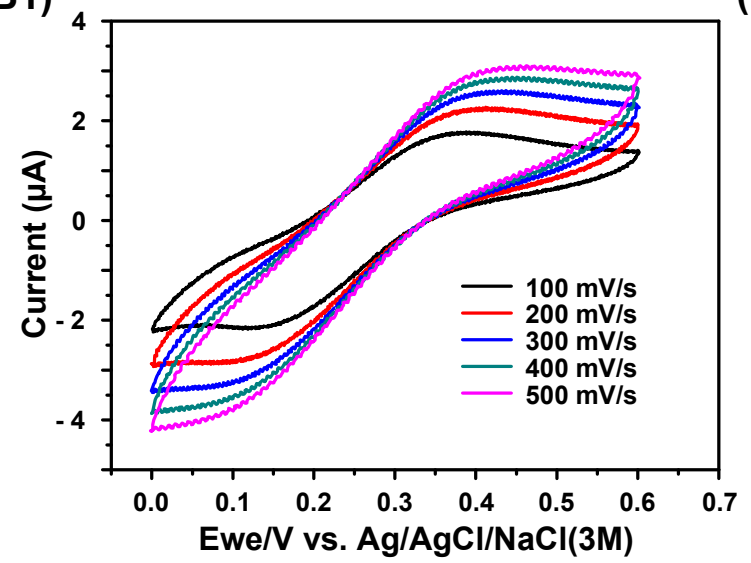

(A2)

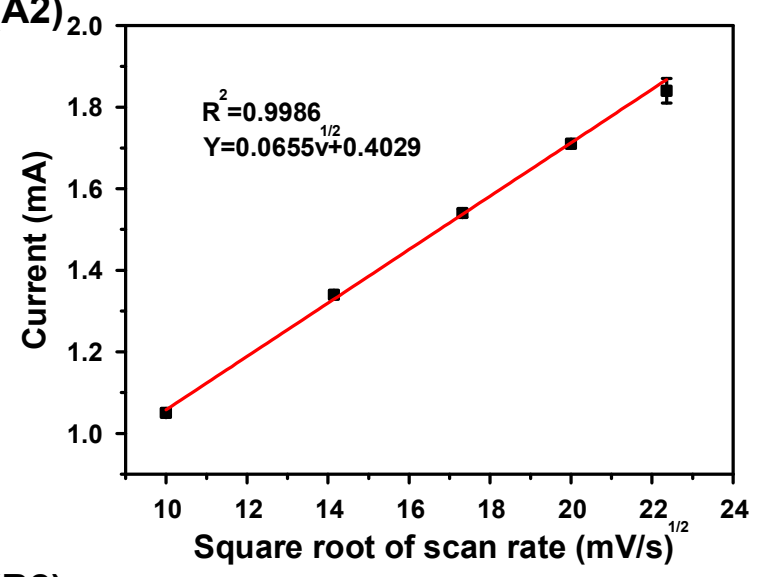

(B2)

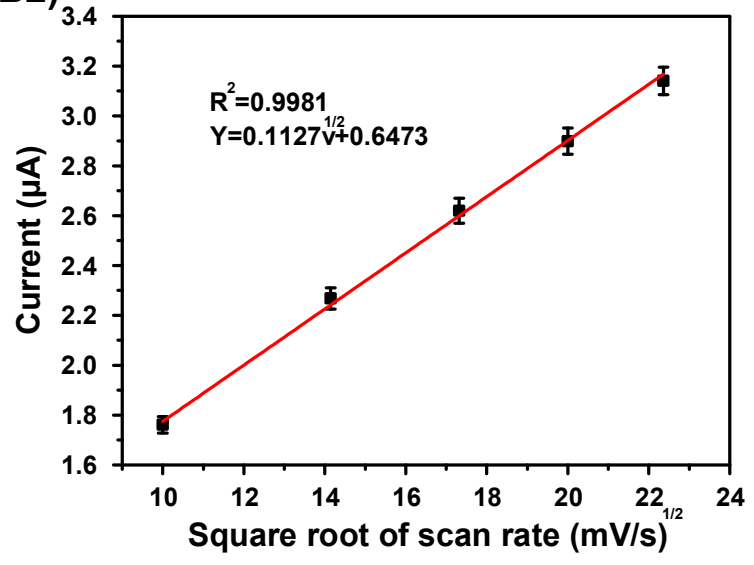

Figure 4. Cont. 
(C1)

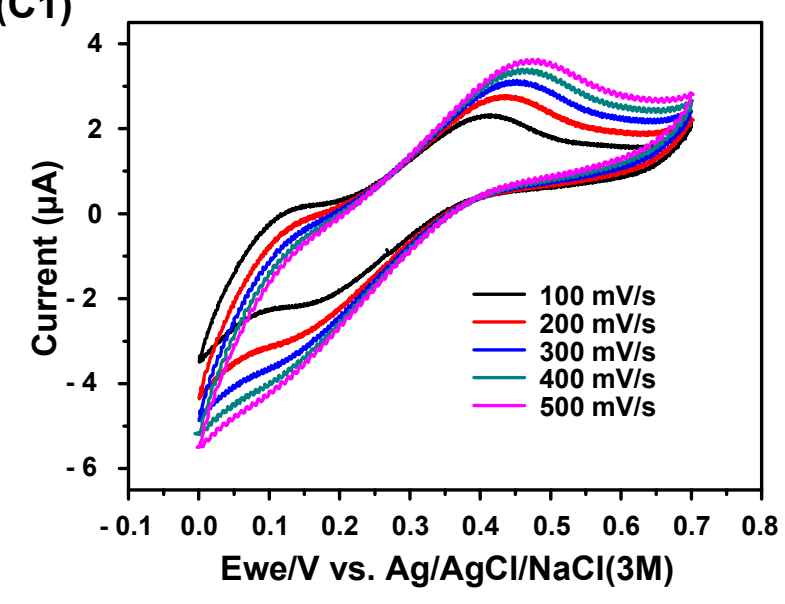

(C2)

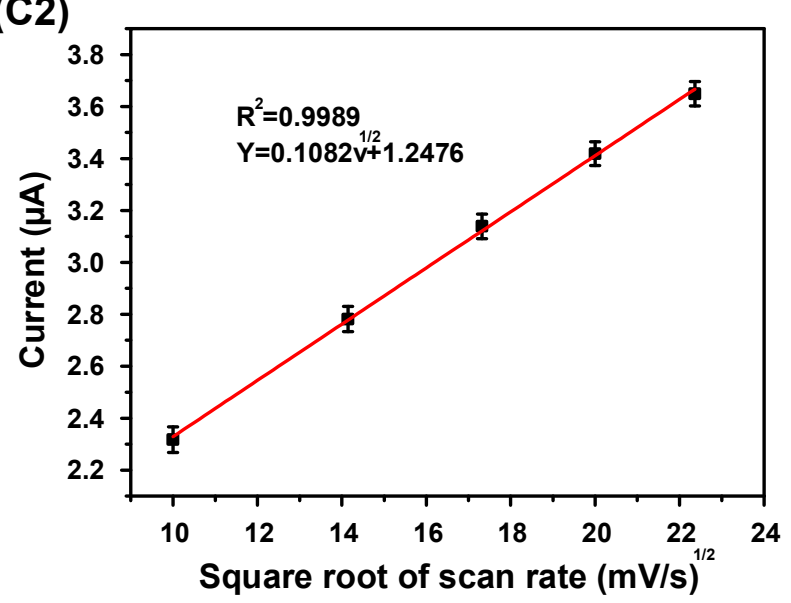

Figure 4. Electrochemical characteristics of the proposed electrode for electrolyte detection: (A1,B1,C1) cyclic voltammograms of the proposed different electrodes at scan rates ranging from 100 to $500 \mathrm{mV} / \mathrm{s}$ in $50 \mathrm{mM} \mathrm{KCl}, 140 \mathrm{mM} \mathrm{NaCl}$, and $1 \mathrm{mM} \mathrm{KCl}$ solutions, respectively; $(\mathbf{A 2}, \mathbf{B} 2, \mathbf{C} 2)$ the corresponding Randles-Sevcik curves of the cyclic voltammograms in (A1,B1,C1), respectively.

\subsection{Detection of $\mathrm{Cl}^{-}, \mathrm{Na}^{+}$, and $\mathrm{K}^{+}$}

Cyclic voltammetry was used for the detection of $\mathrm{Cl}^{-}(\mathrm{KCl})$ because it can be easily oxidized by gold with a suitable oxidation potential. Square-wave voltammetry was adopted for the detections of $\mathrm{Na}^{+}(\mathrm{NaCl})$ and $\mathrm{K}^{+}(\mathrm{KCl})$ because the oxidation process involved the ISM.

\section{(1) $\mathrm{Cl}^{-}$detection}

Figure 5 shows the detection results of $\mathrm{Cl}^{-}$with various concentrations $(25,50,100,150$, and $200 \mathrm{mM}$ ). Clear oxidation and reduction current peaks can be observed in Figure 5A. The absolute value of the oxidation and reduction peak currents increased with the increase in $\mathrm{Cl}^{-}$concentration. Figure $5 \mathrm{~B}$ displays the corresponding calibration curve for $\mathrm{Cl}^{-}$ detection, with the normal concentration range of $\mathrm{Cl}^{-}$in human blood identified by a bar icon. The linear detection range, sensitivity, correlation coefficient, relative standard deviation (RSD), and recovery rate of the electrode were calculated to be 5-200 $\mathrm{mM}$, $0.27 \mathrm{~mA} \mathrm{mM}^{-1} \mathrm{~cm}^{-2}, 0.9988,0.79 \%$, and $101 \%$, respectively.

(A)

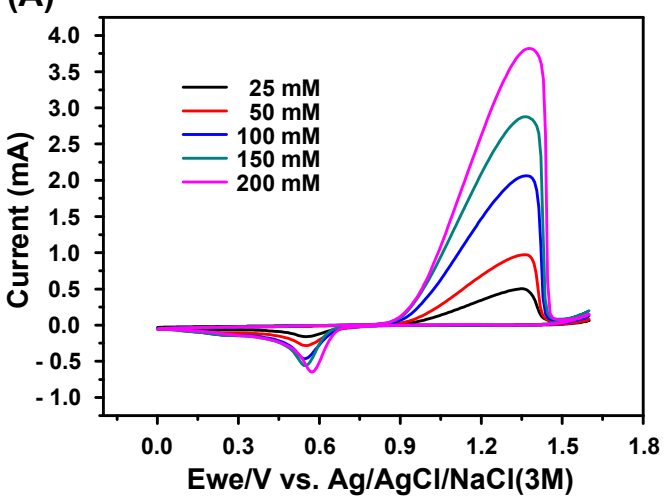

(B)

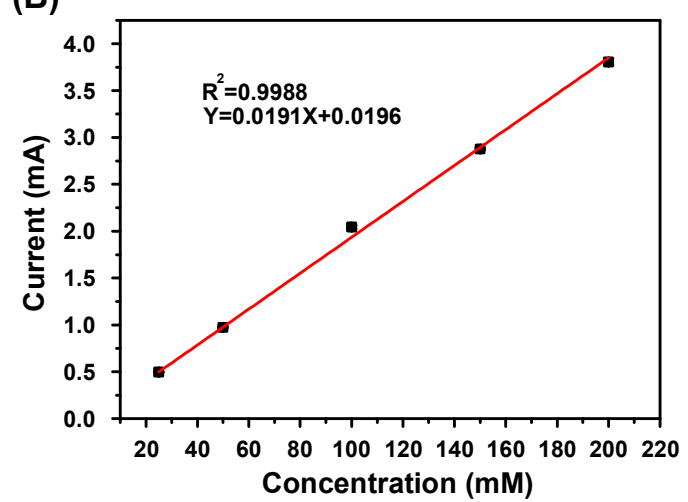

Figure 5. $\mathrm{Cl}^{-}$detection using cyclic voltammetry (CV): (A) cyclic voltammograms $(100 \mathrm{mV} / \mathrm{s})$ for various $\mathrm{Cl}^{-}$concentrations (25-200 mM); (B) linear calibration curve representing the relation between the stable oxidization peak current and concentration; scanning range: $0-1.6 \mathrm{~V}, \mathrm{~N}=3$. 


\section{(2) $\mathrm{Na}^{+}$detection}

Figure 6 shows the SWV detection results of $\mathrm{Na}^{+}$with various concentrations $(50,100$, 150, and $200 \mathrm{mM}$ ). Figure 6 A displays clear oxidation current peaks, which increase with the increase in the $\mathrm{Na}^{+}$concentrations. Figure $6 \mathrm{~B}$ shows the corresponding calibration curve for $\mathrm{Na}^{+}$detection, with the normal $\mathrm{Na}^{+}$concentration range in human blood marked by a bar icon. The linear detection range, sensitivity, correlation coefficient, RSD, and recovery rate of the electrode were calculated to be $50-200 \mathrm{mM}, 0.125 \mu \mathrm{A} \cdot \mathrm{mM}^{-1} \mathrm{~cm}^{-2}$, $0.9786,1.65 \%$ and $100 \%$, respectively.

(A)

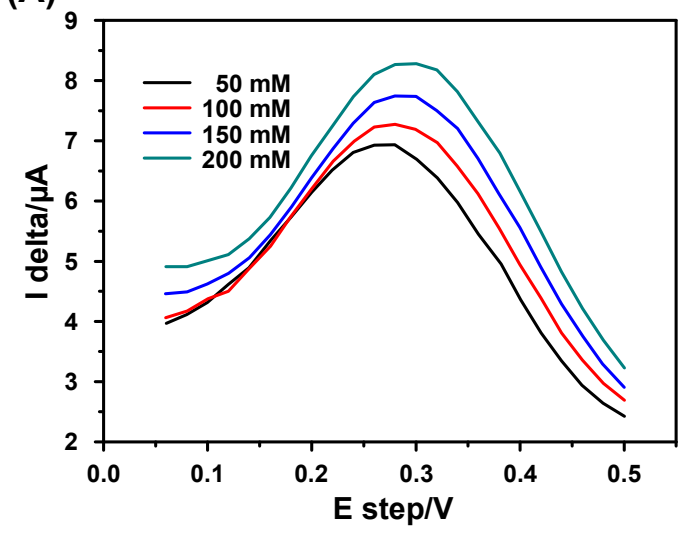

(B)

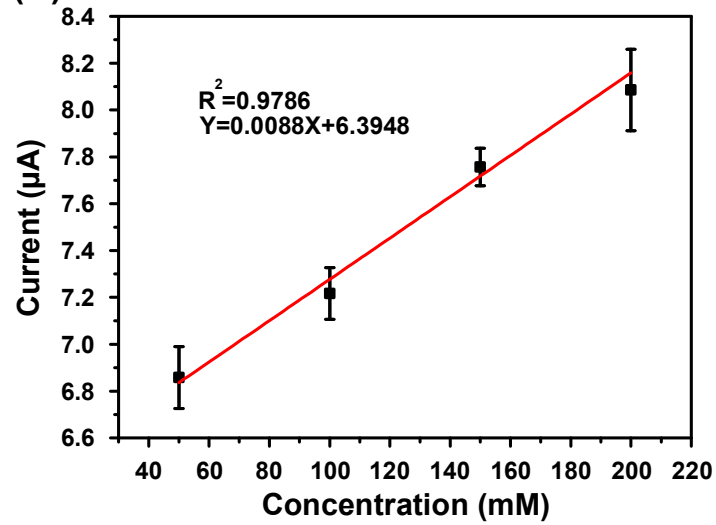

Figure 6. $\mathrm{Na}^{+}$detection using square-wave voltammetry (SWV): (A) cyclic voltammograms $(100 \mathrm{mV} / \mathrm{s})$ for various $\mathrm{Na}^{+}$ concentrations (50-200 mM); (B) linear calibration curve representing the relation between the stable oxidization peak current and concentration; scanning range: $0-0.5 \mathrm{~V}$, pulse height $100 \mathrm{mV}$, pulse width $200 \mathrm{~ms}$, step height $20 \mathrm{mV}, \mathrm{N}=3$.

\section{(3) $\mathrm{K}^{+}$detection}

The SWV detection results of $\mathrm{K}^{+}$with various concentrations $(2,3.5,5,7.5$, and $10 \mathrm{mM})$ are shown in Figure 7. In Figure 7A, the oxidation current peaks increase with increasing $\mathrm{K}^{+}$concentrations. Figure 7B shows the corresponding quadratic calibration curve for $\mathrm{K}^{+}$ detection, which is more appropriate for fitting the measured data. The detection range, sensitivity, correlation coefficient, RSD, and recovery rate of the electrode were measured to be $2-10 \mathrm{mM}, 0.56-7.98 \mu \mathrm{A} \cdot \mathrm{mM}^{-1} \mathrm{~cm}^{-2}, 0.9778,0.47 \%$, and $96 \%$, respectively.

(A)

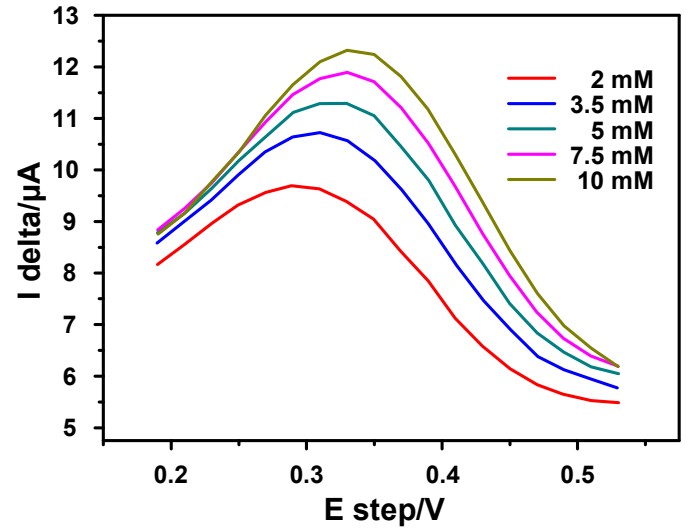

(B)

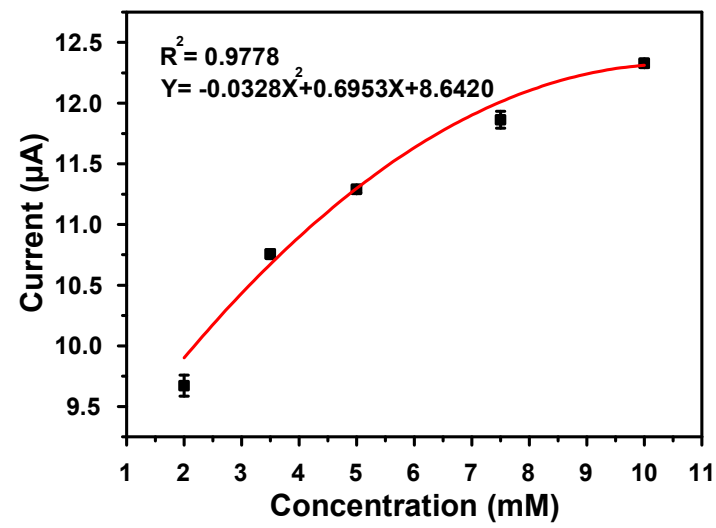

Figure 7. SWV detection results of $\mathrm{K}^{+}$with various concentrations: (A) cyclic voltammograms $(100 \mathrm{mV} / \mathrm{s})$ for various $\mathrm{K}^{+}$ concentrations (2-10 mM); (B) quadratic calibration curve representing the relation between the stable oxidization peak current and concentration; scanning range: $0.2-0.6 \mathrm{~V}$, pulse height $100 \mathrm{mV}$, pulse width $200 \mathrm{~ms}$, step height $20 \mathrm{mV}, \mathrm{N}=3$. 


\section{(4) Interference detection}

We used normal concentrations of $\mathrm{Na}^{+}, \mathrm{K}^{+}, \mathrm{Cl}^{-}, \mathrm{Ca}^{2+}$, and $\mathrm{Mg}^{2+}$ in human blood to examine the influence of interference substances on the oxidation current response of different electrodes. The experimental results are depicted in Figure 8.

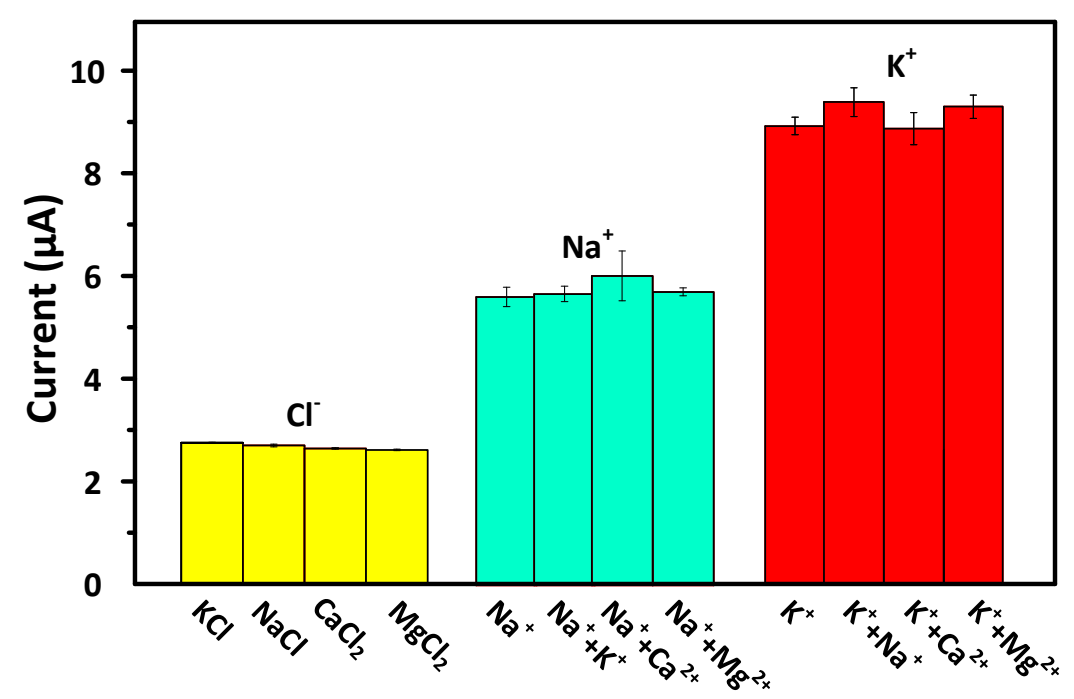

Figure 8. Interferences detection. $\mathrm{Cl}^{-}$detection: $100 \mathrm{mM} \mathrm{KCl}, 100 \mathrm{mM} \mathrm{NaCl}, 50 \mathrm{mM} \mathrm{CaCl}$, and $50 \mathrm{mM} \mathrm{MgCl} 2 ; \mathrm{Na}^{+}$detection: $140 \mathrm{mM} \mathrm{NaCl}$ separately mixed with $4 \mathrm{mM} \mathrm{KCl}, 2.5 \mathrm{mM} \mathrm{CaCl}_{2}$, and $1 \mathrm{mM} \mathrm{MgCl} 2$; $\mathrm{K}^{+}$detection: $4 \mathrm{mM} \mathrm{KCl}$ separately mixed with $140 \mathrm{mM} \mathrm{NaCl}, 2.5 \mathrm{mM} \mathrm{CaCl}$, and $1 \mathrm{mM} \mathrm{MgCl}_{2}$.

The results of the $\mathrm{Cl}^{-}$detection interference experiments (Figure 8) showed that the oxidation currents of four chlorides $\left(\mathrm{KCl}, \mathrm{NaCl}, \mathrm{CaCl}_{2}\right.$, and $\left.\mathrm{MgCl}_{2}\right)$ having the same concentration $(100 \mathrm{mM})$ were between 1.84 and $1.94 \mathrm{~mA}$, with an average current of $1.89 \mathrm{~mA}$. The RSD was calculated to be $2.35 \%$. The experimental results indicate that the $\mathrm{Cl}^{-}$detection electrode was not interfered by cations.

The results of the $\mathrm{Na}^{+}$detection interference experiments (Figure 8) showed that the current response of the $\mathrm{Na}^{+}$detection electrode in the $\mathrm{NaCl}$ solution was $5.55 \mu \mathrm{A}$. After $\mathrm{KCl}, \mathrm{CaCl}_{2}$, and $\mathrm{MgCl}_{2}$ were added to the $\mathrm{KCl}$ solution, the current interferences were measured to be $1.08 \%, 7.31 \%$, and $1.68 \%$, respectively. Among the introduced compounds, $\mathrm{CaCl}_{2}$ had the greatest impact on the current response. However, there was no statistically significant difference between the current response of the $\mathrm{NaCl}$ solution containing any of the three interference substances and that of the pure $\mathrm{NaCl}$ solution. The experimental results show that the proposed $\mathrm{Na}^{+}$detection electrode has good selectivity.

As shown in Figure 8, the current response of the $\mathrm{K}^{+}$detection electrode in pure $\mathrm{KCl}$ solution was measured to be $8.92 \mu \mathrm{A}$. The current interferences after the addition of $\mathrm{NaCl}$, $\mathrm{CaCl}_{2}$, and $\mathrm{MgCl}_{2}$ were measured to be $5.23 \%, 1.01 \%$, and $4.21 \%$, respectively. Similar to the results of the interference experiment of the $\mathrm{Na}^{+}$detection electrode, there was no statistically significant difference between the current response of the $\mathrm{KCl}$ solution containing any of the three interference substances and that of the pure $\mathrm{KCl}$ solution. The experimental results show that the proposed $\mathrm{K}^{+}$detection electrode possesses good selectivity.

\subsection{Performance Comparisons}

In recent years, the electrochemical techniques for measuring electrolyte concentration have been rapidly increasing. The materials for $\mathrm{Cl}^{-}$detection electrode are mostly nanoand micro-structures of carbon, silver, and platinum. Sodium-ion detection electrode materials are mainly manganese oxide-modified carbon and iron sulfate-modified glass carbon. Potassium ion electrode materials include manganese oxide nanorod-modified carbon electrode as well as carrier- and DNA-modified gold electrode. Table 2 compares the 
detection performances of the proposed detection electrodes and the existing technologies. The proposed detection electrode has characteristics such as the ability to be prepared under relatively simple process conditions, excellent detection sensitivity, and low RSD, and the detection linear range is suitable for the chloride, sodium, and potassium ions concentrations in human serum.

Table 2. Performance comparison of the proposed ion detection electrode and existing technologies.

\begin{tabular}{|c|c|c|c|c|c|}
\hline Ions & Electrodes & $\begin{array}{l}\text { Sensitivity } \\
\left(\mu \mathrm{A} \cdot \mathbf{m M}^{-1}\right)\end{array}$ & $\begin{array}{l}\text { Linear Range } \\
\text { (mM) }\end{array}$ & $\begin{array}{c}\text { RSD } \\
(\%)\end{array}$ & Reference \\
\hline \multirow{5}{*}{$\mathrm{Cl}^{-}$} & $\mathrm{Ag} / \mathrm{SPE}$ & 1.98 & 10-200 & $<10$ & [2] \\
\hline & AgGNP/SPE & 0.0000193 & $0.0005-0.09$ & 2.22 & [22] \\
\hline & SPPtE & -24.147 & $0.76-150$ & 5.8 & [23] \\
\hline & 3D-GN/CPE & 0.044 & $0.5-1000$ & - & {$[25]$} \\
\hline & This study & 19.1 & 25-200 & 0.79 & \\
\hline \multirow{3}{*}{$\mathrm{Na}^{+}$} & $\mathrm{Mn}_{3} \mathrm{O}_{4} / \mathrm{CPE}$ & 19.5 & $0.02-0.2$ & - & [26] \\
\hline & $\mathrm{FePO}_{4} / \mathrm{GCE}$ & 0.015 & $25-250$ & - & [42] \\
\hline & This study & 0.126 & $50-200$ & 1.65 & \\
\hline \multirow{4}{*}{$\mathrm{K}^{+}$} & $\mathrm{MnO}_{2}$ nanorods/GCE & 0.0004 & $0.002-0.09$ & - & [21] \\
\hline & $\begin{array}{l}\text { 4-aminobenzo-18-Crown-6 } \\
\text { ether/11-Mercaptoundecanoic acid/Au }\end{array}$ & - & $0.5-7$ & - & [43] \\
\hline & DNA/Au & 113 & $10^{-7}-100$ & $<5$ & [44] \\
\hline & This study & $0.56-7.98$ & $2-10$ & 0.47 & \\
\hline
\end{tabular}

Note: Normal $\mathrm{Cl}^{-}, \mathrm{Na}^{+}, \mathrm{K}^{+}$concentrations in human blood: $98-106 \mathrm{mM}, 135-145 \mathrm{mM}$, and 3.5-5 mM, respectively.

\section{Conclusions}

In this study, $\mathrm{Cl}^{-}, \mathrm{Na}^{+}$, and $\mathrm{K}^{+}$detection electrodes were successfully developed through a simple process to effectively improve the electrolyte detection speed and obtain an appropriate linear detection range, good sensitivity, RSD and recovery rate. Through CV and SWV, the detection data can be obtained in two minutes. The linear detection ranges in the standard samples of $\mathrm{Cl}^{-}, \mathrm{Na}^{+}$, and $\mathrm{K}^{+}$were measured to be $25-200 \mathrm{mM}, 50-200 \mathrm{mM}$, and $2-10 \mathrm{mM}$, with the average RSDs of $0.79 \%, 1.65 \%$, and $0.47 \%$, respectively, and the average recovery rates of $101 \%, 100 \%$ and $96 \%$, respectively. The proposed detection electrode has characteristics such the ability to be prepared under relatively simple process conditions, excellent detection sensitivity, and low RSD; moreover, the detection linear range is suitable for the $\mathrm{Cl}^{-}, \mathrm{Na}^{+}$, and $\mathrm{K}^{+}$concentrations in human serum.

Author Contributions: Conceptualization, G.-J.W. and L.-D.C.; methodology, G.-J.W. and L.-D.C.; validation, G.-J.W. and L.-D.C.; formal analysis, G.-J.W. and W.-J.W.; data curation, L.-D.C.; writingoriginal draft preparation, G.-J.W.; writing-review and editing, G.-J.W. and W.-J.W.; supervision, G.-J.W.; funding acquisition, G.-J.W. All authors have read and agreed to the published version of the manuscript.

Funding: This research was funded by the Ministry of Science and Technology of Taiwan, grant number MOST-109y-002.

Institutional Review Board Statement: Not applicable.

Informed Consent Statement: Not applicable.

Data Availability Statement: The data that support the findings of this study are available from the corresponding author upon reasonable request.

Conflicts of Interest: The authors declare no conflict of interest.

\section{References}

1. Berend, K.; van Hulsteijn, L.H.; Gans, R.O. Chloride: The queen of electrolytes? Eur. J. Intern. Med. 2012, 23, 203-211. [CrossRef]

2. Cinti, S.; Fiore, L.; Massoud, R.; Cortese, C.; Moscone, D.; Palleschi, G.; Arduini, F. Low-cost and reagent-free paper-based device to detect chloride ions in serum and sweat. Talanta 2018, 179, 186-192. [CrossRef] 
3. Pohl, H.R.; Wheeler, J.S.; Murray, H.E. Sodium and potassium in health and disease. In Interrelations between Essential Metal Ions and Human Diseases; Sigel, A., Sigel, H., Sigel, R., Eds.; Springer: Dordrecht, The Netherlands, 2013; Volume 13, pp. $29-47$.

4. Yan, Y.; Shapiro, J.I. The physiological and clinical importance of sodium potassium ATPase in cardiovascular diseases. Curr. Opin. Pharmacol. 2016, 27, 43-49. [CrossRef] [PubMed]

5. Taghizadeh-Behbahani, M.; Hemmateenejad, B.; Shamsipur, M.; Tavassoli, A. A paper-based length of stain analytical device for naked eye (readout-free) detection of cystic fibrosis. Anal. Chim. Acta 2019, 1080, 138-145. [CrossRef] [PubMed]

6. Altunok, I.; Aksel, G.; Eroğlu, S.E. Correlation between sodium, potassium, hemoglobin, hematocrit, and glucose values as measured by a laboratory autoanalyzer and a blood gas analyzer. Am. J. Emerg. Med. 2019, 37, 1048-1053. [CrossRef]

7. Budak, Y.U.; Huysal, K.; Polat, M. Use of a blood gas analyzer and a laboratory autoanalyzer in routine practice to measure electrolytes in intensive care unit patients. BMC Anesthesiol. 2012, 12, 17. [CrossRef] [PubMed]

8. Gibbons, M.; Klim, S.; Mantzaris, A.; Dillon, O.; Kelly, A. How closely do blood gas electrolytes and haemoglobin agree with serum values in adult emergency department patients: An observational study. Emerg. Med. Australas. 2018, 31, 241-246. [CrossRef]

9. Uysal, E.; Acar, Y.A.; Kutur, A.; Cevik, E.; Salman, N.; Tezel, O. How reliable are electrolyte and metabolite results measured by a blood gas analyzer in the ED? Am. J. Emerg. Med. 2016, 34, 419-424. [CrossRef]

10. Yi, H.; Shi, W.; Zhang, Y.; Zhu, X.; Yu, Y.; Wang, X.; Dai, Z.; Lin, Y. Comparison of electrolyte and glucose levels measured by a blood gas analyzer and an automated biochemistry analyzer among hospitalized patients. J. Clin. Lab. Anal. 2020, 34 , e23291. [CrossRef]

11. Gonzalez, A.L.; Waddell, L.S. Blood Gas Analyzers. Top. Companion Anim. Med. 2016, 31, 27-34. [CrossRef]

12. Chen, J.; Gorman, M.; Oreilly, B.; Chen, Y. Analytical evaluation of the epoc ${ }^{\circledR}$ point-of-care blood analysis system in cardiopulmonary bypass patients. Clin. Biochem. 2016, 49, 708-712. [CrossRef]

13. I-STAT POCT System. International Institute for Running Medicine. Available online: https://racemedicine.org/wp-content/ uploads/2019/08/iSTAT_Presentation.pdf (accessed on 31 January 2021).

14. Electrolyte Measuring System SPOTCHEMTM EL SE-1520 I Operating Manual, ARKRAY, Inc. Available online: https:/ / www. woodleyequipment.com/docs/el_operating_manual.pdf (accessed on 31 January 2021).

15. Gao, W.; Emaminejad, S.; Nyein, H.Y.Y.; Challa, S.; Chen, K.; Peck, A.; Fahad, H.M.; Ota, H.; Shiraki, H.; Kiriya, D.; et al. Fully integrated wearable sensor arrays for multiplexed in situ perspiration analysis. Nat. Cell Biol. 2016, 529, 509-514. [CrossRef]

16. Jin, J.-H.; Kim, J.; Lee, S.; Choi, S.; Park, C.; Min, N. A fully integrated paper-microfluidic electrochemical device for simul-taneous analysis of physiologic blood ions. Sensors 2018, 18, 104. [CrossRef] [PubMed]

17. Parrilla, M.; Ortiz-Gómez, I.; Cánovas, R.; Salinas-Castillo, A.; Cuartero, M.; Crespo, G.A. Wearable Potentiometric Ion Patch for On-Body Electrolyte Monitoring in Sweat: Toward a Validation Strategy to Ensure Physiological Relevance. Anal. Chem. 2019, 91, 8644-8651. [CrossRef] [PubMed]

18. Sempionatto, J.R.; Nakagawa, T.; Pavinatto, A.; Mensah, S.T.; Imani, S.; Mercier, P.; Wang, J. Eyeglasses based wireless electrolyte and metabolite sensor platform. Lab Chip 2017, 17, 1834-1842. [CrossRef]

19. Braiek, M.; Djebbi, M.A.; Chateaux, J.-F.; Jaffrezic-Renault, N. A conductometric sensor for potassium detection in whole blood. Sens. Actuators B Chem. 2016, 235, 27-32. [CrossRef]

20. Day, C.; Søpstad, S.; Ma, H.; Jiang, C.; Nathan, A.; Elliott, S.; Frankl, F.K.; Hutter, T. Impedance-based sensor for potassium ions. Anal. Chim. Acta 2018, 1034, 39-45. [CrossRef]

21. Ahn, M.-S.; Ahmad, R.; Yoo, J.-Y.; Hahn, Y.-B. Synthesis of manganese oxide nanorods and its application for potassium ion sensing in water. J. Colloid Interface Sci. 2018, 516, 364-370. [CrossRef]

22. Chen, Z.; Guo, J.; Zhang, S.; Chen, L. A one-step electrochemical sensor for rapid detection of potassium ion based on structureswitching aptamer. Sens. Actuators B Chem. 2013, 188, 1155-1157. [CrossRef]

23. Cunha-Silva, H.; Arcos-Martinez, M.J. Development of a selective chloride sensing platform using a screen-printed plat-inum electrode. Talanta 2019, 195, 771-777. [CrossRef] [PubMed]

24. Cuartero, M.; Crespo, G.A.; Bakker, E. Ionophore-Based Voltammetric Ion Activity Sensing with Thin Layer Membranes. Anal. Chem. 2016, 88, 1654-1660. [CrossRef]

25. Zhang, M.; Wang, C.; Zhang, Z.; Ye, J.; Fang, P. A novel carbon paste electrode for sensitive, selective and rapid electro-chemical determination of chloride ion based on three-dimensional graphene. Sens. Actuators B Chem. 2019, 299, 126951. [CrossRef]

26. Machini, W.B.; Martin, C.S.; Martinez, M.T.; Teixeira, S.R.; Gomes, H.M.; Teixeira, M.F. Development of an electro-chemical sensor based on nanostructured hausmannite-type manganese oxide for detection of sodium ions. Sens. Actuators B Chem. 2013, 181, 674-680. [CrossRef]

27. Han, T.; Mattinen, U.; Bobacka, J. Improving the Sensitivity of Solid-Contact Ion-Selective Electrodes by Using Coulometric Signal Transduction. ACS Sens. 2019, 4, 900-906. [CrossRef] [PubMed]

28. Kondratyeva, Y.O.; Tolstopjatova, E.G.; Kirsanov, D.O.; Mikhelson, K.N. Chronoamperometric and coulometric analysis with ionophore-based ion-selective electrodes: A modified theory and the potassium ion assay in serum samples. Sens. Actuators $B$ Chem. 2020, 310, 127894. [CrossRef]

29. Hu, J.; Stein, A.; Bühlmann, P. Rational design of all-solid-state ion-selective electrodes and reference electrodes. TrAC Trends Anal. Chem. 2016, 76, 102-114. [CrossRef] 
30. El-Rahman, M.K.A.; Zaazaa, H.E.; Abbas, S.S.; El-Zeany, B.; El-Sherif, Z.A.; El-Haddad, D.A. A comparative study of liquid and solid inner contact roxatidine acetate ion-selective electrode membranes. Chin. Chem. Lett. 2015, 26, 714-720. [CrossRef]

31. Van De Velde, L.; D'Angremont, E.; Olthuis, W. Solid contact potassium selective electrodes for biomedical applications-A review. Talanta 2016, 160, 56-65. [CrossRef] [PubMed]

32. Yu, K.; He, N.; Kumar, N.; Wang, N.; Bobacka, J.; Ivaska, A. Electrosynthesized polypyrrole/zeolite composites as solid contact in potassium ion-selective electrode. Electrochim. Acta 2017, 228, 66-75. [CrossRef]

33. Xu, K.; Cuartero, M.; Crespo, G.A. Lowering the limit of detection of ion-selective membranes backside contacted with a film of poly(3-octylthiophene). Sens. Actuators B Chem. 2019, 297, 126781. [CrossRef]

34. Emaminejad, S.; Gao, W.; Wu, E.; Davies, Z.A.; Nyein, H.Y.Y.; Challa, S.; Ryan, S.P.; Fahad, H.M.; Chen, K.; Shahpar, Z.; et al. Autonomous sweat extraction and analysis applied to cystic fibrosis and glucose moni-toring using a fully integrated wearable platform. Proc. Natl. Acad. Sci. USA 2017, 114, 4625-4630. [CrossRef] [PubMed]

35. Liu, Y.; Liu, Y.; Meng, Z.; Qin, Y.; Jiang, D.; Xi, K.; Wang, P. Thiol-functionalized reduced graphene oxide as self-assembled ion-to-electron transducer for durable solid-contact ion-selective electrodes. Talanta 2020, 208, 120374. [CrossRef] [PubMed]

36. Paczosa-Bator, B.; Cabaj, L.; Pięk, M.; Piech, R.; Kubiak, W.W. Carbon-Supported Platinum Nanoparticle Solid-State Ion Selective Electrodes for the Determination of Potassium. Anal. Lett. 2015, 48, 2773-2785. [CrossRef]

37. Criscuolo, F.; Taurino, I.; Stradolini, F.; Carrara, S.; De Micheli, G. Highly-stable Li+ ion-selective electrodes based on noble metal nanostructured layers as solid-contacts. Anal. Chim. Acta 2018, 1027, 22-32. [CrossRef]

38. Xu, J.; Li, F.; Tian, C.; Song, Z.; An, Q.; Wang, J.; Han, D.; Niu, L. Tubular Au-TTF solid contact layer synthesized in a mi-crofluidic device improving electrochemical behaviors of paper-based potassium potentiometric sensors. Electrochim. Acta 2019, $322,134683$. [CrossRef]

39. Paczosa-Bator, B.; Pięk, M.; Piech, R. Application of Nanostructured TCNQ to Potentiometric Ion-Selective K+and Na+Electrodes. Anal. Chem. 2015, 87, 1718-1725. [CrossRef]

40. Mohammadtaheri, M.; Ramanathan, R.; Bansal, V. Emerging applications of metal-TCNQ based organic semiconductor charge transfer complexes for catalysis. Catal. Today 2016, 278, 319-329. [CrossRef]

41. Yuan, B.; Xu, C.; Zhang, R.; Lv, D.; Li, S.; Zhang, D.; Liu, L.; Fernandez, C. Glassy carbon electrode modified with 7,7,8,8tetracyanoquinodimethane and graphene oxide triggered a synergistic effect: Low-potential amperometric detection of reduced glutathione. Biosens. Bioelectron. 2017, 96, 1-7. [CrossRef] [PubMed]

42. Suherman, A.L.; Lin, M.; Rasche, B.; Compton, R.G. Introducing insertive stripping voltammetry: Electrochemical deter-mination of sodium ions using an iron (III) phosphate-modified electrode. ACS Sens. 2020, 5, 519-526. [CrossRef]

43. Kumbhat, S.; Singh, U. A potassium-selective electrochemical sensor based on crown-ether functionalized self assembled monolayer. J. Electroanal. Chem. 2018, 809, 31-35. [CrossRef]

44. Chai, H.; Ma, X.; Meng, F.; Mei, Q.; Tang, Y.; Miao, P. Electrochemical aptasensor based on a potassium ion-triggered DNA conformation transition and self-assembly on an electrode. New J. Chem. 2019, 43, 7928-7931. [CrossRef] 